\title{
Performance of West African Dwarf (WAD) bucks fed differently processed poultry droppings
}

\author{
Okah, U.,* Anokwuru, R.K and Onyearu,V.O. \\ College of Animal Science and Animal Production \\ Michael Okpara University of Agriculture, Umudike \\ P.M.B.,7267, Umuahia, Abia State, Nigeria. \\ *Corresponding author: E-mail: okahuc@yahoo.co.uk
}

\begin{abstract}
A 56 day trial was carried out to evaluate the response of West African Dwarf (WAD) bucks fed processed poultry dropping. Nine (9) West African Dwarf (WAD) bucks were assigned to three treatment groups in a completely randomized design (CRD) experiment with 3 bucks per treatment. The diets contained poultry dropping at $0 \%\left(T_{\nu}\right), 10 \%$ sun dried poultry dropping $\left(S D P D, T_{2}\right)$ and $10 \%$ toasted poultry dropping $\left(T P D, T_{3}\right)$. The parameters evaluated included: dry matter intake (DMI), changes in body weight, feed conversion ratio (FCR), heart girth $(H G C)$, body length (BLC) and height at withers, hematological and biochemical indices, and carcass characteristics of the bucks. Proximate analyses of the sun-dried poultry dropping, toasted poultry dropping, the treatment diets and the forages (Panicum maximum and Centrocema spp.) were also carried out. Concentrate dry matter intakes were $184.65 \mathrm{~g}$, $150.05 \mathrm{~g}$ and $183.62 \mathrm{~g}$ while forage dry matter intakes were $494.04 \mathrm{~g}, 569.70 \mathrm{~g}$ and $555.66 \mathrm{~g}$ for $T_{1}, T_{2}$, and $T_{3}$ respectively. Concentrate dry matter intake was similar $(P>0.05)$ in $T_{1}$ and $T_{3}$ groups, but significantly $(P<0.05)$ higher than the $T_{2}$ group. The $T_{2}$ group consumed significantly higher $(P<0.05)$ forage than the $T_{1}$ and $T_{3}$ groups. $H G C$ and $H W C$ were $5.67 \mathrm{~cm}$, $2.33 \mathrm{~cm}$ and $4.67 \mathrm{~cm}$, and $5.00 \mathrm{~cm} 4.67 \mathrm{~cm}$ and $4.00 \mathrm{~cm}$ respectively. $T_{1}$ and $T_{3}$ had higher $H G C$ than $T_{2}$ group, while the $T_{2}$ group recorded higher $H W C$ than the $T_{1}$ and $T_{3}$ groups. The hemoglobin $(\mathrm{Hb})$ values varied significantly $(p<0.05)$ among the treatment means, and they were, $12.30,11.30$ and $12.00 \mathrm{~g} / \mathrm{dl}$ respectively. $P C V(\%)$ and $W B C\left(x 10^{3} / \mathrm{mm}^{3}\right.$ varied significantly $(p<0.05)$ and the values were 37.00, 34.00 and $36.00(\%)$, and 39.00, 56.07 and $42.50\left(\times 10^{3} / \mathrm{mm}^{3}\right.$ respectively. Neutrophil and lymphocyte were also influenced significantly, the values were, $15.00,10$, and $31.00 \%$, and $83.00,86.00$, and $66.00 \%$ respectively. Only serum urea was affected among the biochemical components, and the values were 0.87, 0.90 and $0.97 \mathrm{mg} / \mathrm{dl}$ respectively. Dressing percentage were $34.62 \%, 37.75 \%$ and $42.60 \%$ for $T_{1}$, $T_{2}$ and $T_{3}$ respectively; the $T_{2}$ and $T_{3}$ groups were similar $(P>0.05)$ but $T_{3}$ was higher than $T_{1}$. The values for shoulder were $10.67 \%, 10,74 \%$ and $8.05 \%$; the full gut values were $47.20 \%$ $38.56 \%$ and $28.68 \%$ for $T_{1}, T_{2}$ and $T_{3}$ respectively. Liver, kidney and heart were $2.90 \%, 2.22 \%$ and $1.93 \% ; 0.55,0.47 \%$ and $0.42 \%$, and $0.72 \%, 0.57 \%$ and $0.58 \%$ for $T_{1}, T_{2}$ and $T_{3}$ respectively. $T_{1}$ showed significantly $(P<0.05)$ higher relative weight values for liver and heart than the T3 group. Inclusion of processed poultry dropping up to 10\% in the diets of WAD bucks did not affect their performance negatively. However simple sun drying is recommended based on the results of this study and it is also a cheaper and straight forward processing method for poultry dropping.
\end{abstract}

Keywords: Bucks, poultry dropping, sun-dried, toasted, dietary, carcass, hematological. 


\section{Introduction}

Nutrition is an important factor that can influence the hematological and biochemical status, cause serious physiological changes which can result in morbidity and even mortality of animals especially in extreme cases of deviation from normal.

The quality and quantity of feeds available to livestock determine the success of their production. The basic reason for the poor performance of livestock in developing countries is the seasonal inadequacy of feed, both in quality and quantity. The recent high cost of feed ingredients has brought about the need to search for alternatives to the conventional feed resources. It is therefore imperative to explore other feed materials that are not competed for by human and industry (Alawa and Umunna, 1993; Okah, 2004; Owen et al, 2008). The limited supply of raw materials for the feed industry has resulted in a continuous increase in the cost of grains in Nigeria and has been related to its scarcity as a result of competition for these feed ingredients. To depend on alternative sources of ingredients, especially when it encourages a shift from ingredients for which there is competition, may help if the former is sufficiently available (Oluyemi and Robert, 2000).

Goat production in the tropics relies mainly on forage and forage by-products. Consequently, the production and provision of good quality forage all year round is imperative for sustainable ruminant livestock production. The unavailability of good quality green, succulent and nutritious forage during dry seasons in the tropics also influence the production of livestock. This is aggravated by the lack of alternative feed resource or supplementation during the critical period (Mpairwe et al., 1998). This explains why most animals under the traditional system of production have poor body conditions at the peak of the dry season. It has been reported (Ademosum, 1988, Adegbola et al., 1998 and Adegbola, 2002) that poor quality roughages when fed to ruminants without supplementation in the dry season caused weight loss and sometimes death of animals.

The poultry industry is one of the largest and fastest growing sectors of the livestock industry in the world with a $35 \%$ increase in meat and egg production in the period from 2000-2008 (FAO, 2010). Rearing of birds has grown from a side-line occupation into a commercial enterprise with single farm housing thousands of birds. The 2010 World Annual Census data, estimated the world flock to be over 18 billion birds with estimated yearly output of 22 million tones of poultry dropping (FAO, 2010). This rapid expansion of the industry over the last few decades has increased the need to find economically and environmentally acceptable ways of utilizing such large quantities of dropping. The use of poultry dropping as a dietary supplement in ruminant ration could have a considerable effect on reducing costs of feeding, insufficiency of protein in diet, and solving disposal problems. Poultry droppings is one type of faeces but its potential as a feed supplement for ruminant animals has been investigated in recent years (Okah et al., 2013). The poultry dropping is rich in protein (about 25\% protein equivalent), Total Digestible Nutrients (TDN) (about $50 \%$ ) as well as minerals. Poultry dropping may replace up to 15 to $25 \%$ of grain diet for ruminant animals. Incorporation of poultry litter into the ration of growing lambs can be as high as $70 \%$, and for fattening stock up to 50\% (FAO, 1985). Much, however, depends upon the litter quality and counterpart forage and feed ingredients. 
The study conducted by Owen et al. (2008) on the proximate composition of heattreated layers litter showed that the material contained $621.41 \mathrm{KcalKg}^{-1} \mathrm{ME}, 87 \% \mathrm{DM}$, $20 \% \mathrm{CP}, 10.40 \% \mathrm{CF}, 2.20 \% \mathrm{EE}$ and $18.50 \%$ total Ash; phosphorus (4.55\%), calcium $(2.00 \%)$, sodium $(0.10 \%)$, potassium $(2.05$ $\%)$ and magnesium $(0.48 \%)$. Teotia and Miller, (1974) reported that the protein quality of maggot infested poultry dropping is comparable with that of meat or fish meal and superior to that of soybean meal. The high content of protein, energy, and minerals in poultry dropping underscore its importance as a partial substitute for concentrates in the diet. The ability of ruminant animals like goats to utilize the non protein nitrogen components in poultry dropping to synthesize protein, along with the fiber-digesting ability of ruminants, suggest that poultry dropping could be considerably valuable as a cattle feed resource. Poultry dropping has high nitrogen and phosphorus content making it a very good organic fertilizer and feed supplement (Ndegwa et al., 1991; Wood, 1992; Leo et al., 2009). In Nigeria, about 932.5metric tonnes of poultry dropping were reported to be produced annually (Adewumi and Adewumi, 1996; Adewumi et al, 2011). This study was, therefore, conducted to evaluate the effect of processing on the potentials of poultry dropping as feed resource for goats.

\section{Materials and Methods}

The study was conducted in the sheep and goat unit of the Teaching and Research farm of the Michael Okpara University of Agriculture, Umudike, in Abia state. Umudike is located on latitude $05^{\circ} 29^{1}$ North, Longitude $07^{\circ} 33^{1}$ east and has altitude of 122 above sea level. The relative humidity ranges from $50-90 \%$. The area is characterized by long duration of rainfall and short period of dry season. Average annual rainfall is $2200 \mathrm{~mm}$ which is evenly distributed over 8 months (MarchNovember) (NRCR I, 2010).

Preparation of test ingredients and experimental diets

About $50 \mathrm{~kg}$ of poultry dropping was collected from the National Root Crop Research Institute Umudike. The poultry dropping was sun-dried for 14days by spreading the dropping on polythene sheet. The dropping was turned from time to time at $30 \mathrm{mins}$ intervals to ensure quick drying, using improvised broom mounted on a short wooden handle. A fraction $(20 \mathrm{~kg})$ of the dried poultry dropping was toasted (about 15mins) using big toasting (frying) pan and a small flame to ensure even distribution of heat. Both, the sun dried and toasted poultry dropping were stored in bags prior to the incorporation into experimental diets. Three diets designated $\mathrm{T}_{1}, \mathrm{~T}_{2}$ and $\mathrm{T}_{3}$ were formulated to contain $0 \%$ poultry dropping, $10 \%$ sun-dried poultry dropping (SDPD) and 10\% toasted poultry dropping (TPD) (Table 1).

Chemical Analysis

Proximate analysis of the dried poultry dropping, toasted poultry dropping, experimental diets, and forages were carried out according to the methods of AOAC (2000).

Experimental animals, design and management

Nine (9) West African Dwarf (WAD) bucks (4-6 months) of age, weighing between 8.33 and $8.67 \mathrm{~kg}$ were bought from local farmers from the University environs for the study. The bucks were quarantined for 21 days, during which the animals were dewormed and also bathed with acaricide against external parasites, using thiabendazole and benzene hexachloride respectively. They were also vaccinated with PPR vaccine to forestall any outbreak 
Table 1: Ingredients composition of experimental diets

\begin{tabular}{lcll}
\hline Ingredient (\%) & T1 & T2 & T3 \\
\hline Maize Offal & 57.25 & 50.25 & 50.25 \\
Wheat Offal & 20.00 & 17.00 & 17.00 \\
SDPD & - & 10.00 & - \\
TPD & - & - & 10.00 \\
Palm Kernel Cake & 21.00 & 21.00 & 21.00 \\
Blood meal & 1.00 & 1.00 & 1.00 \\
Salt & 0.50 & 0.50 & 0.50 \\
Vit/min Premix* & 0.25 & 0.25 & 0.25 \\
\hline Total & 100 & 100 & 100 \\
\hline SDPD - Dried Poultry Dropping; TPD-Toasted Poultry Dropping; * Broiler Vit/min Premix: \\
Each 2.5kg contains: Vit.A-10,000,000IU; Vit.D3-2,000,000IU; Vit.E- 20,000IU; Vit. K-2,250mg; \\
Thiamine-1750mg; Riboflavin-5,000mg;Pyridoxine-2,750mg; Niacin- 27,500mg; Vit. B12- 15mg; \\
Pantothenic acid-7,500mg; Folic acid - 7,500mg; Biotin50mg; Choline chloride- 400g; \\
Antioxidant-125g; Manganese-80g; Zinc-50g; Iron-20g;Copper-5g; Iodine- 1.5g; \\
Selenium-200mg and Cobalt-200mg
\end{tabular}

of the disease. The bucks were randomized into three groups and assigned to the three dietary treatments in a completely randomized design (CRD) with each buck serving as a replicate and housed in individual pens. The experimental diets were offered at $3 \%$ body weight at about $8 \mathrm{hr}$ in the morning while the forage (Panicum maximum and Centrocema spp.) was offered at about $12 \mathrm{hr}$. Feed intake was recorded by measuring the difference between the quantity of concentrate and forage offered and the refusal. The initial weight and linear measurements, body length, heart girth, height at withers of each buck was taken. Feed conversion ratio was calculated by dividing the daily dry matter intake by the daily weight gain. Blood samples were drawn from each animal through the jugular vein using a $12 \mathrm{ml}$ gauge $(6 \mathrm{~cm})$ needle to draw $10 \mathrm{ml}$ of blood on the $56^{\text {th }}$ day of the study. The blood samples were divided into two; first lot $(5 \mathrm{ml})$ was emptied into heparinized packs containing about 40mg of anti coagulant components. The second lot $(5 \mathrm{ml})$ was collected with anti-coagulant free bottles, and was used to determine blood biochemical components. Haematological (PCV, Hb, WBC Neutrophils, Lymphocytes) and serum chemistry (serum total and cojugated bilirubin, urea, glucose, ALP, ALT) were determined using commercial kits of Randox Laboratories Limited. The bucks were fasted for 24 hours before slaughter, according to Okah (2006). They were weighed just before slaughter, after slaughter and after dressing. Dressing percentage was calculated as the weight of dressed warm carcass in relation to body weight before slaughter. A dressed (warm) carcass is defined as the weight of the animals less the head, skin, thoracic contents and pelvic cavities (including the diaphragm and kidney) and the limbs (distal to the carpal and tarsal) joints (Okah, 2006). The heart, the liver less the gall bladder, the lungs, the spleen, the pelvic fat and the four feet were weighed. The gut was weighed full and empty. Data collected were subjected to a one-way analysis of variance (ANOVA) according to Steel and Torrie (1980). Significantly different means were separated using Duncan's multiple range 
test (Duncan, 1955) using SAS (2001).

\section{Results and Discussion}

The Proximate composition of the experimental diets, test ingredients and forages are shown in table 2. The performance of the bucks fed processed poultry dropping is presented in Table 3. Table 4 represents the hematology and serum biochemistry of the bucks fed processed poultry dropping. Table 5 shows the carcass characteristics of West African Dwarf bucks fed differently processed poultry dropping.

The crude protein contents of the SDPD $(25.78 \%)$ and TPD (23.97\%) obtained in this study are similar to $25.50 \%$ reported by Devendra and Rooghavan, (1978) and
Lamidi, (1995), higher than $11.60 \%$ by Muller, (1976), 16.50\% (Adegbola et al., 1990) and 20.00\% (Owen et at., 2008), but lower than the $27.90 \%$ by Hadjipanayiotou, (1994). The crude fiber values of 4.59 and $3.59 \%$ reported for SDPD and TPD were lower than the $16.20 \%$ (Muller, 1976) and $10.40 \%$ (Owen et at., 2008). Total ash values of 5.48 and $6.23 \%$ obtained for SDPD and TPD respectively were lower than the $20.10 \%$ (Muller, 1976), 11.60\% (Hadjipanayiotou, 1994) and $18.50 \%$ (Owen et at., 2008). Owen et al. (2008) also obtained higher ME value of 621.41 $\mathrm{Kcal} / \mathrm{Kg}$ than the $316.31337 .38 \mathrm{Kcal} / \mathrm{Kg}$ reported in this study. The composition of poultry dropping (faecal matter) depends on the nutrient composition of the diet fed,

Table 2: Proximate composition of experimental diets, test ingredients and forages

\begin{tabular}{|c|c|c|c|c|c|c|c|}
\hline & $T_{1}$ & $T_{2}$ & $T_{3}$ & $S D P D$ & $T P D$ & $\begin{array}{l}\text { Panicum } \\
\text { max. }\end{array}$ & $\begin{array}{l}\text { Centrocema } \\
\text { spp. }\end{array}$ \\
\hline Dry matter & 90.68 & 91.04 & 91.04 & 86.91 & 91.76 & 89.68 & 89.84 \\
\hline Crude protein & 14.56 & 15.86 & 15.67 & 25.78 & 23.97 & 6.13 & 16.36 \\
\hline Crude fibre & 18.42 & 15.92 & 15.46 & 4.59 & 3.59 & 31.20 & 18.60 \\
\hline $\begin{array}{l}\text { Nitrogen } \quad \text { fre } \\
\text { extract }\end{array}$ & 47.38 & 47.64 & 48.69 & 49.27 & 55.88 & 51.87 & 51.37 \\
\hline Ether extract & 4.60 & 4.82 & 4.80 & 1.79 & 1.99 & 1.86 & 3.44 \\
\hline Ash & 5.72 & 6.80 & 6.42 & 5.48 & 6.23 & 8.94 & 10.23 \\
\hline $\mathrm{ME}(\mathrm{KCal} / \mathrm{gDM})$ & 289.16 & 297.38 & 300.64 & 316.31 & 337.38 & 248.74 & 301.88 \\
\hline
\end{tabular}

Table 3: Performance of West African Dwarf rams fed differently processed dietary poultry dropping

\begin{tabular}{lllll}
\hline Parameter & $\boldsymbol{T}_{\boldsymbol{l}}$ & $\boldsymbol{T}_{2}$ & $\boldsymbol{T}_{3}$ & $\boldsymbol{S E M}$ \\
\hline Initial body weight $(\mathrm{g})$ & 8333.33 & 8333.33 & 8666.67 & 1054.09 \\
Finial body weight $(\mathrm{g})$ & 8933.33 & 9033.33 & 9300 & 1036.38 \\
Body weight change $(\mathrm{g})$ & 600.00 & 700.00 & 633.33 & 60.86 \\
Daily body weight change $(\mathrm{g})$ & 12.24 & 14.44 & 12.93 & 1.29 \\
Concentrate daily dry matter intake $(\mathrm{g})$ & $184.65^{\mathrm{a}}$ & $150.05^{\mathrm{b}}$ & $183.62^{\mathrm{a}}$ & 0.58 \\
Forage daily dry matter intake $(\mathrm{g})$ & $494.04^{\mathrm{c}}$ & $569.70^{\mathrm{a}}$ & $555.66^{\mathrm{b}}$ & 0.38 \\
Total daily dry intake $(\mathrm{g})$ & 678.02 & 719.75 & 800.49 & 35.35 \\
Feed conversion ratio & 56.78 & 51.08 & 62.93 & 5.34 \\
Heart girth change HGC $(\mathrm{cm})$ & $5.67^{\mathrm{a}}$ & $2.33^{\mathrm{b}}$ & $4.67^{\mathrm{a}}$ & 0.33 \\
Body length change BLC $(\mathrm{cm})$ & 4.33 & 4.67 & 3.67 & 0.33 \\
\hline Height at withers change $(\mathrm{cm})$ & $5.00^{\mathrm{a}}$ & $4.67^{\mathrm{a}}$ & $4.00^{\mathrm{b}}$ & 0.19 \\
\hline a,b & &
\end{tabular}

${ }^{a, b}$ Means within the same row with different superscript differ significantly $(p<0.05)$ 
Performance of West African dwarf bucks fed processed poultry droppings

Table 4: The Hematological and biochemical of WAD bucks fed processed poultry dropping

\begin{tabular}{|c|c|c|c|c|}
\hline Parameters & $T_{1}$ & $T_{2}$ & $T_{3}$ & SEM \\
\hline \multicolumn{5}{|l|}{ Haematological values } \\
\hline Haemoglobin $(\mathrm{Hb}) \mathrm{g} / \mathrm{dl}$ & $12.30^{\mathrm{a}}$ & $11.30^{\mathrm{c}}$ & $12.00^{\mathrm{b}}$ & 0.05 \\
\hline Packed Cell Volume (PCV)(\%) & $37.00^{\mathrm{a}}$ & $34.00^{\mathrm{b}}$ & $36.00^{\mathrm{a}}$ & 0.47 \\
\hline White Blood Cell (WBC) $\left(\times 10^{3} / \mathrm{mm}^{3}\right.$ & $39.00^{\mathrm{c}}$ & $56.07^{\mathrm{a}}$ & $42.50^{\mathrm{b}}$ & 1.37 \\
\hline Neutrophil (\%) & $15.00^{\mathrm{b}}$ & $10.00^{\mathrm{c}}$ & $31.00^{\mathrm{a}}$ & 0.47 \\
\hline Lymphocyte $(\%)$ & $83.00^{\mathrm{b}}$ & $86.00^{\mathrm{a}}$ & $66.00^{\mathrm{c}}$ & 0.58 \\
\hline Eosinophil (\%) & 2.33 & 3.00 & 2.33 & 0.43 \\
\hline \multicolumn{5}{|l|}{ Biochemical values } \\
\hline Total Bilirubin (mg/dl) & 10.00 & 10.00 & 9.67 & 0.19 \\
\hline Conjugated bilirubin (mg/dl) & 13.33 & 13.33 & 12.33 & 0.33 \\
\hline Urea $(\mathrm{mg} / \mathrm{dl})$ & $0.87^{\mathrm{b}}$ & $0.90^{\mathrm{a}}$ & $0.97^{\mathrm{a}}$ & 0.04 \\
\hline Creatinine (mg/dl) & 0.40 & 0.43 & 0.39 & 0.02 \\
\hline Glucose (mg) & 35.67 & 36.33 & 36.00 & 0.79 \\
\hline AST (I.U/1) & 61.00 & 78.00 & 79.00 & 0.58 \\
\hline ALT (I.U/1) & 0.90 & 0.63 & 0.63 & 0.22 \\
\hline
\end{tabular}

${ }_{a, b, c}$ Means within the same row with different superscript differ significantly $(p<0.05)$

AST $=$ Serum Aspatate Aminotransferase,$\quad$ ALT $=$ Serum Alanine Aminotransferase

Table 5: Carcass characteristics of West African Dwarf bucks fed differently processed poultry dropping

\begin{tabular}{lllll}
\hline Parameter & $\mathbf{T}_{1}$ & $\mathbf{T}_{\mathbf{2}}$ & $\mathbf{T}_{3}$ & SEM \\
\hline Live weight at slaughter(g) & 7500.00 & 7550.00 & 7000.00 & 236.29 \\
Empty live weight (\%) & 5100.00 & 5450.00 & 5500.00 & 298.61 \\
Warm carcass (g) & 2550.00 & 2850.00 & 3000.00 & 187.08 \\
Dressed weight (\%) & $34.62^{\mathrm{b}}$ & $37.75^{\mathrm{ab}}$ & $42.60^{\mathrm{a}}$ & 1.50 \\
Leg (\%) & 11.02 & 11.69 & 9.20 & 1.08 \\
Loin (\%) & $13.15^{\mathrm{a}}$ & $11.04^{\mathrm{a}}$ & $8.05^{\mathrm{b}}$ & 0.82 \\
Set (\%) & 8.74 & 10.64 & 8.41 & 0.66 \\
Ends & 8.93 & 7.27 & 6.47 & 0.70 \\
Shoulder (\%) & $10.67^{\mathrm{a}}$ & $10.74^{\mathrm{a}}$ & $8.05^{\mathrm{b}}$ & 0.63 \\
Abdominal fat (\%) & 2.38 & 1.62 & 0.79 & 0.48 \\
Bone to-lean ration & 0.32 & 0.32 & 0.62 & 0.09 \\
Head (\%) & 14.04 & 12.86 & 11.80 & 1.29 \\
Skin (\%) & 9.87 & 11.94 & 10.36 & 0.91 \\
Feet (\%) & 4.94 & 4.46 & 4.49 & 0.33 \\
Full gut (\%) & $47.20^{\mathrm{a}}$ & $38.56^{\mathrm{ab}}$ & $28.68^{\mathrm{b}}$ & 3.34 \\
Empty gut (\%) & $12.49^{\mathrm{a}}$ & $10.39^{\mathrm{b}}$ & $8.08^{\mathrm{c}}$ & 0.48 \\
Liver (\%) & $2.90^{\mathrm{a}}$ & $2.22^{\mathrm{b}}$ & $1.93^{\mathrm{b}}$ & 0.14 \\
Kidney (\%) & $0.53^{\mathrm{a}}$ & $0.47^{\mathrm{ab}}$ & $0.42^{\mathrm{b}}$ & 0.03 \\
Heart (\%) & $0.720^{\mathrm{a}}$ & $0.57^{\mathrm{b}}$ & $0.58^{\mathrm{b}}$ & 0.04 \\
Spleen (\%) & 0.24 & 0.16 & 0.18 & 0.03 \\
Lungs (\%) & 3.68 & 1.78 & 1.86 & 1.07 \\
Pelvic fat (\%) & 0.11 & 0.08 & 0.08 & 0.03 \\
Testicles & 1.07 & 0.97 & 0.64 & 0.14 \\
\hline
\end{tabular}

$\overline{\mathrm{a}}^{\mathrm{a}, \mathrm{c}, \mathrm{c}}$ Means within the same row with different superscripts differ significantly $(\mathrm{P}<0.05)$. 
level of nutrient utilization, physiological status of the birds and processing method of the poultry dropping.

The daily body weight changes obtained in the three treatments $\mathrm{T}_{1}(12.24 \mathrm{~g}), \mathrm{T}_{2}(14.44 \mathrm{~g})$ and $\mathrm{T}_{3}(12.93 \mathrm{~g})$ did not differ significantly $(\mathrm{P}>0.05)$. The concentrate and forage dry matter intakes indicated significant $(\mathrm{P}<0.05)$ differences among the treatment means. The $\mathrm{T}_{2}(10 \% \mathrm{SDPD})$ group recorded lower $(\mathrm{P}<0.05)$ concentrate dry matter intake. The lower dry matter intake by the $\mathrm{T}_{2}$ group might be due to traces of offensive odour in the poultry dropping after sundrying which was eliminated by toasting leading to improved dry matter intake in $\mathrm{T}_{3}$. Feed intake had earlier been reported to be depressed by odour and fibre content of diets (Bamgbose et al., 2004; Okah, 2006). However, the lower intake in the $\mathrm{T}_{2}$ group was compensated by higher forage dry matter intake by the group. Khan et al. (2004) and Chineke, et al. (2013) had earlier reported that inclusion of poultry litter in the diets of sheep and goats improved dry matter and crude protein intake due to enhanced microbial fermentation. The body lengths of the animals were not affected by the treatment. Heart girth of animals, though significantly $(\mathrm{P}<0.05)$ influenced, did not follow any trend. Height at withers was significantly $(\mathrm{P}<0.05)$ higher in groups 1 and 2 . It appears that sun-dried poultry dropping supported the growth of bone length than the toasted poultry dropping. This probably might suggest that toasting affected the minerals especially calcium content of the poultry dropping.

The hemoglobin $(\mathrm{Hb})$ concentration of animals fed the treatment diets were significantly $(\mathrm{P}<0.05)$ depressed. It appears that there were some traces of hemolytic substances in the poultry dropping, especially the $T_{2}$ (sun-dried) group which resulted in reduced hemoglobin levels of the group. However, the animals were not anemic as the $\mathrm{Hb}$ levels of all the three treatment groups which ranged from 11.30 to $12.30 \mathrm{~g} / \mathrm{dl}$ were within the normal range of 8.00 to $12.00 \mathrm{~g} / \mathrm{dl}$ for goats (Banerjee, 2005). All the diets promoted PCV of the animals, which seem to indicate that the protein quality of the diets were adequate for the animals' physiological functions (Jain, 1986). Total white blood cell counts were significantly $(p<0.05)$ higher in the poultry dropping diets. The animals fed diet $2\left(\mathrm{~T}_{2}\right)$ had the highest value, which seem to confirm the lower $\mathrm{Hb}$ recorded by the same group. The white blood cell differentials (neutrophil, lymphocyte) were significantly $(p<0.05)$ influenced by the treatment diets, but did not follow any trend. However, the lymphocyte level was higher in $\mathrm{T}_{2}$ group and was also the case for WBC. The higher WBC and lymphocyte recorded for the $T_{2}$ group might be due to traces of foreign substances that probably slightly triggered immune response by the animals in that group. The urea levels of $\mathrm{T}_{2}$ and $\mathrm{T}_{3}$ groups were significantly $(\mathrm{p}<0.05)$ higher than the $T_{1}$ group, although the analyzed protein content of the diets were close. It has been established that blood urea nitrogen level is a good indicator of the concentration of rumen ammonia (Lee et al., 1978). The higher urea levels for animals fed diets containing poultry dropping might be due to the slow release of ammonia from the non-protein nitrogenous compound (uric acid) present in poultry dropping resulting in the sustained appearance of urea in the peripheral blood of the animals. Abdel-Baset and Abbas (2010) reported that uric acid as a major content of poultry waste can be utilized by rumen microbes for protein synthesis as it is not easily dissolved in the rumen fluid and ammonia is only slowly released, and so 
making it more efficiently utilized than other non-protein nitrogenous sources.

The treatments significantly $(\mathrm{P}<0.05)$ influenced the dressing percentage of the bucks. The values, $34.62 \%, 37.75 \%$ and $42.60 \%$ for $\mathrm{T}_{1}, \mathrm{~T}_{2}$ and $\mathrm{T}_{3}$ respectively was higher in $\mathrm{T}_{3}$ than $\mathrm{T}_{1}$, but $\mathrm{T}_{2}$ was an interphase. The 37.75 and $42.60 \%$ for processed poultry dropping were close to the 40.35 and $32.13 \%$ for $20 \%$ and $30 \%$ poultry dropping and maggot combination reported by Okah et al. (2013). The higher dressing percentage seems to suggest that the nutrients in diets containing poultry dropping were highly degradable and metabolizable, hence resulting in better conversion to body tissues. All the dressing percentage values reported in this study were higher than the $27.77 \%$ reported by Okah et al. (2013) for bucks fed 10\% poultry dropping and maggot combination. However, variation in dressing percentage of animals, apart from being influenced by age and breed, might also depend on whether or not the edible offals are included (Okah,2006). Of all the meat cuts (leg, loin, set, ends and shoulder), only the loin and shoulder were significantly $(\mathrm{P}<0.05)$ affected by the treatment. The loin, $13.15 \%$, $11.04 \%$ and $8.05 \%$, and shoulder, $10.67 \%$, $10.74 \%$ and $8.05 \%$ for $\mathrm{T}_{1}, \mathrm{~T}_{2}$ and $\mathrm{T}_{3}$ respectively were higher in $\mathrm{T}_{1}$ and $\mathrm{T}_{2}$ than $\mathrm{T}_{3}$. The range of the loin $8.05 \%$ to $13.15 \%$ were close to the $8.70 \%$ to $12.17 \%$ for bucks fed poultry dropping and maggot combination. The shoulder values of $10.33 \%$ to $24.97 \%$ (Okah et al., 2013) are higher than the range of $8.05 \%$ to $10.74 \%$ in this study. The carcass and the cut parts values will depend on how well the nutrients were utilized by the animals to synthesize body tissues. The abdominal fat of $2.38,1.62$ and $0.79 \%$ was significantly $(\mathrm{P}<0.05)$ lower in the $\mathrm{T}_{3}$ than $\mathrm{T}_{1}$. The lower abdominal fat content in the $\mathrm{T}_{3}$ group might be due to lower energy level of $\mathrm{T}_{3}$ diet which probably was only adequate for animals' physiological functions without any excess for fat deposition. Bone-to lean ratios were $0.32,0.32$ and 0.62 for the $T_{1}, T_{2}$ and $T_{3}$ respectively. Significantly $(\mathrm{P}<0.05)$ higher bone-to-lean ratio in the $\mathrm{T}_{3}$ group seems to suggest that the toasting of poultry droppings probably affected the Ca: $\mathrm{P}$ in a manner that promoted bone mass in the animals.

The full and empty gut values were significantly $(p<0.05)$ higher in the control group ( $0 \%$ poultry dropping) than the groups on poultry dropping diets. The relative organ weights (liver, kidney, heart and testicles) were significantly $(\mathrm{p}<0.05)$ higher in the control, showing that there were no much toxic substances in poultry dropping that could trigger detoxification activity by these organs and subsequent hypertrophy. The results of this study showed that poultry dropping promoted the growth of somatic cells for flesh deposition, but discouraged the growth of visceral organs. This agrees with the earlier report by Aro and Tewe (2007), that feeding poultry waste does not contribute to increase in visceral organ size, hence no diversion of nutrients meant for the growth of edible carcass.

\section{Conclusion and Recommendation}

Poultry dropping is a promising alternative feed resource not only for monogastric animals as have been reported by many researchers, but highly recommended for ruminants feeding because of their ability to utilize non-protein nitrogen (NPN) like uric acid, which is the main NPN in poultry dropping. There was no negative effect observed in the physiological functions of animals fed $10 \%$ processed poultry dropping. The $\mathrm{T}_{2}$ (10\% sun-dried poultry dropping) showed better animal 
performance. Being a quicker process and with relatively better animal performance, the sun-drying of poultry dropping is hereby recommended. However, studies with higher inclusion levels might be necessary to establish its optimal dietary level.

\section{References}

Abdel- Baset, N. S. and Abbas S. F. 2010. Study on the use of dried poultry litter in the camel's ration. Vet. Res. For. 2:65-71.

Adegbola, A.A., Ogbonna, R.C and Nwachukwum E.E.1988. Nutrient intake, digestibility and rumen studies in goats fed varying levels of cassava peels and brewer's dried grains. Nig. J . Anim. Prod. 15: 161-166.

Adegbola, A. A. 2002. Nutrient intake, digestibility and rumen metabolites. 1 . Bulls fed rice straw with or without supplements. Nig. J. Anim. Prod.29: 40-48

Adegbola, A. A., Smith, O. B. and Okeudo, N. J. 1990. Response of West African dwarf sheep fed cassava peels and poultry manure based diet. Proceedings of the $1^{\text {st }}$ joint workshop, Lilongwe-Malawi, 16-19 ${ }^{\text {th }}$ December, pasture Network for Eastern and Southern African Resource Network for Agricultural By-products (ARNAB).

Adegbola, A. A., Smith, O. B. and Okeudo, N. J. 1990. Response of West African dwarf sheep fed cassava peels and poultry manure based diet. Proceedings of the $1^{\text {st }}$ joint workshop, Lilongwe-Malawi, 16-19 ${ }^{\text {th }}$ December, pasture Network for Eastern and Southern African Resource Network for Agricultural By-products (ARNAB).

Adegbola, A. A., Smith, O. B. and
Okeudo, N. J. 2010. Response of West African Dwarf Sheep fed cassava peel and poultry manure based diets. FAO Corporate Document Repository produced by ILRI, pp: 1-8.

Ademosum ,A.A. 1988. The potential of small ruminants in meeting the protein needed for Nigeria. Paper presented at the 13th Annual Conference of Nigerian Society for Animal Production Calabar, Nigeria. P. 25.

Adewumi, A. A., Adewumi, I. K. and Olaleye, V. F. 2011. Livestock waste menace: Fish wealth-solution. African Journal of Environmental Science Technology 5: 149-154.

Adewumi, I. K. and Adewumi, A. A. 1996. Managing poultry wastea, A paper presentation. Proceedings of the workshop on indigenous knowledge and biotechnology, September 16-24, 1996, Obafemi Awolowo.

Alawa, J. P. and Umunna, N. N. 1993. Alternative feed formulation in the developing countries: prospects for utilization of agroindustrial by-products. J. Anim. Prod. Res. 13: 63-98.

AOAC. 2000. Association of Official Analytical Chemists. Official Methods of Analysis, $17^{\text {th }}$ edn. Published by Associatio of Offcial Analytical Chemists, Washington D.C.

Aro, S. O and Tewe, O. O. 2007. Performance and Carcass yield of barrows fed dried poultry waste as replacement for palm kernel cake. Africa .J. Biotech 6 (4): 487492.

Bamgbose, A.M., Abioye, S., Oboh, S.O.Aruna, M.B., Isah, O.A., Obasohan, E.E., Omoikhoje, S.O. and Imasuen, J.A.2004. Response of broilers to dietary levels of processed 
pigeon pea meal, Proc. $9^{\text {th }}$, Ann. Conf. Anim. Sci. Ass. of Nig . (ASAN), Ebonyi State University, Abakaliki, Nigeira, $13^{\text {th }}-16^{\text {th }}$ September, pp 2325.

Banerjee, G.C. 2005. Animal Husbandry $\left(8^{\text {th }}\right.$ Ed). Bidhan Chendra Krishi Viswaivdyalaya. Pp. 99-111.

Chineke, C.M., Fajemisin, A.N., Adedeji, A.E., Fajemisin, A.J and Olaiya, O. 2013. Effect of processing on the nutritive value of corn cobs fed to West African Dwarf rams, Proc. 38th Annual Conference of Nigerian Society for Animal Production 17th 20th March, 2013, RUST, Port Harcourt, Rivers State, Nigeria, pp.201-204.

Devendra,C and Rooghavan, C. V.1978. Agricultural by-products in Smith, East Asia: Availability, utilization and potential value. Wld Rev. Anim. Prod. 14: 11-27.

Duncan, D.B.1955. New multiple range and multiple F-tests. Biometrics 14: 145

El-Sabban, F.F, Hatzler, B., Long, J.W., Frear, T.A., Elf, D., Centry, R. F.1970. Value of processed

poultry wastes as feed for ruminants. J. Anim. Sci. 31:107-111.

Fajemisin, A.N. 1994. Utilization of poultry dropping by sheep fed cassava waste- based diet. M.Sc. Thesis Presented to the Department of Animal Science, University of Ibadan, Nigeria, pp. 5-56.

FAO. 1985. Production year book, Food and Agricultural Organisation.Rome, Italy.

FAO.2010. Agricultural Handbook: Poultry Meat and Eggs. 1st edition, Food and Agricultural Organisation Investment Center Division, Rome Italy.
Hadjipanayiotou, M. 1984. The use of poultry litter as ruminant feed in Cyprus. Wld Anim. Rev. 49: 32-38.

Jain, N.C. 1986. Scanning electron micrograph of blood cells. In: Schalm's Veterinary haematology. 4th ed. Lea and Febiger. Philadelphia.

Khan, M.A., Sarwa, M., Nisa, $M$ and Khan, M.S. 2004. Influence of hexose on feeding value of urea treated corn cobs in lactating crossbred cows. Asian-Aust. J. Anim.Sci. 7:70.

Lamidi, O. S. 1995. Poultry manure as supplement for cattle grazing the natural pastures. M.Sc. Thesis; Department of Animal Science, Ahmadu Bello University, ZariaNigeria.

Lee, A.J., Twardock, A.R., Dubar, B.H., Hall, J.E. and Davis, C.L. 1978. Blood metobolic profiles: their use and relation to nutritional status of dairy cows. J. Dairy Sci.,. 61: 16521670.

Leo, E., Nathan, S. Morteza, M. and Michael, D.,2009. The use of poultry litter in row crops. Agriculture and Natural resources, Cooperative extension Service, University of Arkansas, USA, pp: 1-3.

Lowman B. G. and Knight D. W. 1970. A note on the apparent digestibility of energy and protein in dried poultry excreta. Animal Production 12: 525528.

Mpairwe, O.R., Sabiiti, E.N., and Mugerwa, J.S 1998. Effect of died Glricidia sepium leaf supplement on feed intake, digestibility and nitrogen retention in sheep fed dried elephant grass ad-libitum. Agro Forestry Systems. 41: 139-150.

Müller, Z. 1976. Economic aspects of 
recycled waste. Proc. Tech. Consult. New Feed Resources (4):245-264, FAO, Rome, 1977.

Ndegwa, P.M., Thompson, D. and Merka, W. C. 1991. Fractionation of Poultry Litter for e $\mathrm{n} \mathrm{h}$ a $\mathrm{n} \mathrm{c}$ e d utilization. Trans. Am. Soc. Agric. Biol. Eng., 34:992-997.

NRCRI 2010. Agro. Meterologic Unit. National Root Crop Research Institute, Umudike,Nigeria.

Okah, U. 2004. Effect of dietary replacement of maize with maize processing waste on the performance of starter broiler chicks. Proceedings of $9^{\text {th }}$ Annual Conference of Animal Science Association of Nigeria. Pp.25.

Okah, U. 2006. Performance of sheep fed varying levels of pigeon pea(Cajanus cajan) seed in the concentrate diets. Ph. D. Dissertation. Michael Okpara University of Agriculture, Umudike, Abia State, Nigeria.

Okah, U., Akpan, A.A. and Okeke, U.I. 2013. Dietary poultry droppings and maggot combination for West African Dwarf (WAD) goat. Int. J. Appl. Res. and Tech. 2(4):92-99.

Oluyemi, J.A and Roberts, F.A 2000. Poultry Production in Warm Wet
Climates $2^{\text {nd }}$ ed. Spectrum Books Ltd. Ibadan Nigeria in Association with Safari books (Export) Ltd, UK and African Books Collective Ltd Oxford.

Owen, O. J., Ngodigba, E. M. and Amakiri, A. O. 2008. Proximate comparison of heat treated poultry litter (layers). International Journal of Poultry Science 7: 1033-1035.

SAS 2001. Users Guide. Statistical Analysis System Procedure, SAS Institute, Inc.Carry North Carolina, USA.

Steel, R.G.D. and Torrie, J.H. 1980. Principles and Procedures of Statistics. ( $2^{\text {nd }}$ edition). McGraw-Hill Inc., Tokyo, Japan 633pp.

Teotia, J.S. and Miller, B.F. 1974. Nutritive content of fly pupae and manure residue (Unpublished report).

Wood, C.W.1992. Broiler litter as a fertilizer. Benefits and environmental concern. Proceedings of the National Poultry Waste Management Symposium,(PWM'92), Auburn, pp:305-312.

Received: $1^{\text {st }}$ April, 2014 Accepted: $27^{\text {th }}$ October, 2014 